\title{
Exploring thesis writing experiences of the master's level students from Nepali universities
}

\author{
Ashok Raj Khati \\ PhD student, Far Western University, Nepal
}

\begin{abstract}
The purpose of this paper is to discuss the thesis writing practices of master's level students in Nepali universities. To discuss the central issue and support the main argument of the paper, I relate some thesis writing anecdotes and experiences of master's level students from the Nepali universities. The central argument of the paper is that thesis writing as a requirement to receive a degree at any cost is based on the traditional model which considers the process of writing as a highly mental and cognitive activity. As this model seems to be incapable of capturing the context in which the writing takes place, the socio-cultural theoretical orientation offering a more culturally sensitive view of academic writing practices has been increasingly gaining recognizable space in Nepali academia.
\end{abstract}

Keywords: Thesis writing, academic writing, socio-cultural practice, master's level, Nepali university

\section{Introduction}

Developing academic writing is an essential skill for the students in higher education to achieve academic success. My experience as a university student shows that learning in higher education mainly requires an ability to write well in a purely academic style. Furthermore, students' academic abilities in higher education are usually evaluated through several writing-related course assignments, research and review papers, thesis writing and journal articles. As the thesis writing is a major requirement to cross the degree in higher education, it has been given the greatest attention in all contexts.

Academic writing also plays a crucial role in socialising students into the discourse of subjects and disciplines in universities (Pineteh, 2014). Various researchers have suggested a number of ways to understand the academic writing practices of the students. One of the ways to understand literacy practices in higher education, particularly academic writing is through a socio cultural lens which is crucial when developing support structures for scholars (Wilmot \& Lotz-Sisitka, 
2015). The model opens the space to study the academic literacy development of the students from the academic socialization view. From this point of view, academic writing is the discursive space which establishes the link between students' entry into disciplinary communities and their acquisition of the formal conventions associated with the academy (Leibowitzet. al. 1997). It indicates that academic writing is not a linear process of learning some conventional set of rules to write; rather it is an evolving process of participating, engaging, interacting and learning institutional and social conventions. Then the development of academic writing can be seen in a continuum, rather than in a fixed point in the form of product.

There are two lines of research on socialization in academic writing in the literature: one focuses on the "product," and the other on the "process". The first, product connects written texts with the concept of academic discourse communities and academic socialization focuses on the students' mastery of rhetorical features specific to the expectations of their academic discourse communities (Morita, 2004). The other line of research on socialization in academic writing attends to the process in which students are socialized. It also incorporates the concept of communities, but the concept of communities is related to the framework of "communities of practice" (Lave \& Wenger, 1991; Wenger, 1998) in which members participate in a social practice. In this process oriented perspective, academic writing is viewed as social practice in which a student participates in the activities situated in various communities of practice.

A valuable component of academic socialization process in higher education can be the collaborative work of thesis writing between the thesis writer and the supervisor. Collaborative writing as a form of academic discourse production involves the negotiation of institutional and disciplinary ideologies (Duff, 2010). As a means of academic socialization, collaborative writing presents a complex dynamics of power, as it invokes competing ideologies governing the roles of students, supervisors, scholars, and coauthors (Darvin \& Norton, 2019). Implying that, students' collaborative process during thesis writing with their supervisors and teachers brings different power relations to play and negotiation of different ideologies.

Regarding thesis writing in English as a Foreign Language (EFL) context, there are a numerous of challenges to learners. Students with no prior experience of academic writing rely on models for academic style that they copy from previous works, 'resulting therefore in what can be described as a loss of voice' (McKinley, 
2017). Thus, academic writing as a literacy practice is not simply about conforming to a set of conventions or disciplinary rules but it is also a cultural and social practice, which involves using different cognitive abilities to negotiate power, authority and identity within the landscape of universities (Beard, Clegg \& Smith 2007; Street, 2004). In this line, Wenger (1998) suggests the negotiation in the social interactions on how students develop new identities in language learning. As writing is a communicative act, situated in a social, cultural setting (Casanave, 2003), it is necessary for a student to establish an awareness of his or her own socio-cultural positionality in relation to others to be able to develop writing skills. McKinley (2017) further explains the concept — students' establishment of an awareness of his or her own socio-cultural positionality_is associated with students' establishing writer identity and developing critical argument. Likewise, Morita (2000) identifies the gap that academic discourse acts as oppressive figure in several socio-cultural setting that constrains the students' voices in the academic conversation, such as in their dissertations. In this connection, examining the thesis writing experiences of master's level students in light with the socio-cultural theoretical model of academic writing can be an important area of investigation in Nepali context.

\section{The Study}

The purpose of the study is to discuss the thesis writing practices and understand the experiences of master's level students on thesis writing process in Nepali universities. The study aims to answer the following single research question:

1. How do the students explain their experiences during the thesis writing process in the university?

As a qualitative researcher, I have employed interpretative paradigm to explore different perspectives of the participants in the study. The stories of four master's level students who have completed their master's level with thesis submission from Nepali universities are the main data sources. Two thesis writers were made to write their reflections and two stories were taken from published reflections of the students. I understand that human experiences, complexities and human centeredness could not be captured just through using statistical tools; therefore, narratives of my research participants provide a way to organize human experience (Kim, 2015). I also conducted semi-structured interview with two of them using interview guidelines questions. The participants were purposively selected in the study. Furthermore, two other anecdotes are the additional data sources to illuminate some issues of thesis writing practices in the Nepali universities. I attempt to relate the anecdotes and the 
stories of thesis writers along with my own experiences of thesis writing to generate the information in the study.

\section{Findings and Discussion}

In the following sections, I initially present some anecdotes to discuss about the thesis writing practices in the universities. Then, I present the stories of the master's level students and analyse them in light with two theoretical orientations of academic writing: the traditional autonomous model and the socio-cultural model.

\section{Thesis writing practices}

Let me begin the discussion with a story. A year ago, one of the 'back paper' students (a student who attempted the board examination more than one time) of master's level came to my residence and requested me to provide a topic for his thesis writing. He told his stories that he was not able to pass the papers in time that would qualify him for writing a thesis. Finally, in two attempts (after two years), he was able to meet the requirements to start the thesis writing process. As he was a high school teacher of English in the western part of Nepal, he further shared that he did not have enough time to go through the overall processes of thesis writing. I could guess that he wanted to complete his thesis writing in any case as early as possible. I offered him some of my ideas on different topics of interest related to ELT (English language teaching). To my surprise, he proposed me to write a proposal for him and he would pay for it. I did not respond to his unethical proposal for a moment. After some time, I persuaded him that I could assist him to review his proposal if he, at least, could prepare a draft. Since then, he went out of my contact. Later, I learned that he hired somebody to work for him.

This is a story of a thesis writer who perceives that a thesis should be submitted at any case and cost as it has been four years to accomplish the master's degree. The student was entirely unfamiliar with the preliminary research activities such as sources of research topics and proposal writing. Karn (2009) states that one of his students (a student from a Nepali university) seemed to have assumed that thesis can be submitted in any manner, and he did not seem to pay any heed that there is a proper style of writing and the theses should adhere and abide by the standards set by the Department. In a similar line, Neupane Bastola (2020) explores that students' focus was on the completion of a thesis rather than learning. Her research participants in the study -ten supervisors, complained that their students were interested only in the completion of their thesis to such an extent that thesis writing was just 'a ritual for the majority' (p. 10). The above anecdote also signifies 
the reasons behind some unethical conduct such as having a thesis written and plagiarism. Most importantly, the context clearly indicates that writing a thesis has merely been a requirement to receive the degree for many students, rather than learning research and academic writing skills.

Let me share another story. A professor had a nasty dispute with a student during his second semester in a university class for some reasons. Their professional relationship collapsed thereafter. Coincidentally, the same professor was assigned as the thesis supervisor to the student at the end. Then the student brought a student union leader and threatened the professor and pressurized him to award marks for the thesis as per his (student's) wish. When the professor tried to persuade him about the thesis writing process, he attempted a physical attack on him with the help of his friends. The student blamed that the professor was not his nomination as a supervisor instead the professor was blamed to take revenge of the past and managed the formal process of appointing himself as a supervisor in the department. Finally, the case grew bigger and bigger among students and professors, and the issue, of course, an academic one was eventually politicalized.

The story is an extreme example of unethical conduct in the university, and it can be analysed from different angles. On the one hand, many students come to the phase of thesis writing with no prior experience of writing anything except in the examination. They do not make themselves well prepared and creative enough to begin the thesis writing process. In this connection, Bhattarai (2009) also observes that students neither examine the research problem critically nor do they defend it satisfactorily. She further mentions that if the thesis supervisor tries to convince them about the right track of the thesis writing process, they feel that they are unnecessarily harassed.

On the other hand, the story also demands the supervisors' awareness of their expected supervisory roles. Tiwari (2019) seems to be very critical of the roles of the thesis supervisor and raised some ethical concerns on the role of thesis guide in the way they were not professionally supportive to students to enhance the collaborative process of writing of the thesis. He further articulated that all his participants in the research voice came in a way that their supervisors were not cooperative and professional in supporting students' thesis writing. For instance, delayed response to students' writing is a major complaint among students. In a similar vein, Sharma, (2017) also points out that thesis supervisors need to consider and be familiar with the expectations of thesis candidates. The scenario evidently depicts that thesis 
writing is taken as the locus of all master's level programs. It further stresses that university departments need to take the necessary steps to change this scenario in terms of the theoretical orientation of the thesis writing process, reconsidering the rationale of making students write theses at any cost and practicalities of thesis writing.

\section{Writing as an autonomous cognitive activity}

As the other side of analysis, thesis writing issue is also deeply rooted in our teaching practices of writing skill right from the school level. In my experience, students were not taught writing as a process-based activity. They are taught about writing not writing itself. Students memorize teachers' notes including essays for the examination purpose. In the university, many students receive several lectures on how to write and they often strive to create original pieces of writing in real ground. To meet the date for submitting assignments, they 'copy and paste' in rush which ultimately leads to the case of plagiarism. They do not receive enough opportunity to practice writing in the classrooms nor do they get feedback on their writing. It indicates that the whole process has been a one-way practice of teaching writing skill.

In my observation, therefore, the problem mainly lies in the theoretical model of implementing the courses of thesis writing. Traditionally, thesis writing has been taken as a highly mental and cognitive activity, an isolated writing activity of the student which is context-independent. Universities conduct mass orientation of students in a single venue regarding the thesis writing guidelines or procedures irrespective of their socio-cultural backgrounds, level of experiences, diverse disciplines, and areas of interest. Students are oriented as a homogeneous group of people in which student's writing is based on relatively homogeneous norms, values, and cultural practices. Homogeneous here refers to the uniform and universal writing norms and practices. Furthermore, they are given 'good' or 'bad' types of feedback in terms of the language they use in their writing. Students do not have much empowering experiences as a one-way socialization process of writing takes place. It is because the traditional model focuses on a set of learnable universal skills for writing a thesis that is separate from the discipline and institutional contexts that considers academic or thesis writing as a predefined set of rules that student writers need to adapt to. Lea and Street (1998) criticise this deficit model which represents student writing as somewhat reductionist meaning, it is dependent on a set of transferable skills, and language proficiency rather than critical thinking. 
This 'one size fits all' model, therefore, is incapable of taking account of culturally sensitive views of academic writing practices as they vary from one context to another. It further ignores that students' writing in higher education is ideological in nature. In our context, universities' departments execute the 'processes' of academic writing and thesis writing entirely from a traditional perspective in the way over-reliance on the 'product' based model has made it more difficult for students to attain and accomplish the work.

\section{Thesis writing as a socio-cultural practice}

Thesis writing, however, is not considered an easy task in all academic contexts even outside Nepal. The experiences -pains and pleasure -of students vary in different contexts. Let me share you two excerpts from two success stories (reflections) of thesis writing in a Nepali university T. Rai (2018) shares her experiences this way:

"During this journey of writing a thesis I experienced most suffering and stressful time, I feel like that a woman suffered during in labour pain. It was in the sense that I had no option escaping from it because I spent about a year preparing this thesis and face several problems, challenges, dilemmas, and fear from the early days of preparing proposal to facing thesis viva. These several painful moments during the process however made me strong and led towards its successful completion".

She compares the thesis writing pain with the labour pain that a woman suffers. It shows the real struggle of a thesis writer from the early days of writing thesis to defending thesis viva at the end. She gets satisfied after going through several stages of thesis writing during that whole year. Likewise, M. Rai (2018) told her story in this way:

No doubt writing a thesis is a hard work. But it becomes harder for students like me who have a limited idea about a subject that I am going to study. My study was always focused on 'how to pass' the exam. I rarely voyaged beyond the prescribed books and rarely generalised the things in life that I have studied. I always had due respect to my teachers and their PowerPoint slides and I became successful to note and rote them. I was like a 'broiler kukhura' (poultry chicken, not free range), who merely depends on others. Since I started writing my Master's thesis, I realised the real sense of reading and writing. 
She brings a powerful message in her reflection as an indication to shift the traditional approach of lecturing, rote learning and receiving the degree. She made an important point that she was just fascinated by the teachers' presentations, obeyed them all the time, and made some notes for the examination during two years of her regular study. However, she realized the real sense of reading and writing that begins only after she started the thesis writing process. It indicates that writing a thesis brings varieties of activities and writing practices on the part of students.

These two thesis writers describe the stories on how a thesis writer in the university experiences writing in an early stage, how they struggle or become a part of different reading, writing activities and other academic practices to accomplish the work. While going through the whole stories of two thesis writers, it provides a sense of academic writing as the process of socialization in an academic community. Here, socialization refers to a locally situated process by which a university student from various linguistic and cultural backgrounds becomes socialized into a new academic community, such as a university department. The process involves the thesis writers' engagement in various academic activities in their communities of practice. Here is another story of a student who shares the experiences of socialization through supervisor's feedback, support from classmates and reading MEd, MPhil and $\mathrm{PhD}$ dissertations:

I would see myself as a blind when I started my journey of thesis writing. Every good or bad experience teaches us some lessons. So did my master's degree thesis writing experience. The journey of thesis writing taught me a good lesson of accepting the challenge and move forward continuously. At first, I felt like I had no skill of writing thesis. I underwent suffocating situation at the beginning of the research. I had no explicit ideas regarding the process of research and writing thesis. I was just stuck on how aspect of research. Later on, I went through so many dissertations written by the MEd, MPhil and PhD graduates that lessened my distress to some extent and helped to frame my research. Moreover, I got the greatest help from my thesis supervisor from the beginning till my dissertation got accepted. Sometime after the feedback from the supervisor, I would feel if it is better to quit the research and go back to my comfort zone. However, my supervisor and other classmates assisted me to move forward. From the whole journey of this research, it taught me the lesson that we get succeed if we decided to come out of comfort zone and kept on enjoying the whole process of thesis writing. 
This is a success story of a thesis writer from one of the Nepali universities. The thesis writer initially was distressed to start the work, but when she got socialized in the department and received support from her supervisors, classmates and upper grade students. She even went through several dissertations which helped her to move forward and built confidence in writing her own thesis. Likewise, another participant put his stories this way:

After the acceptance of my proposal by the research committee of viva for proposal, I started collecting of data. I frequently consulted my supervisors. In each conference, he provided me new insights and feedback on my work. At initial, I had a feeling that it is so tough to address the comments from the supervisors. But later, I also consulted some previous works related to my study and came in touch with other thesis writers. The process made me feel enjoying the thesis writing work. Finally, on the day of viva of my thesis, I was feeling so happy as I have completed my thesis. During the writing of thesis, I was able to make my wider academic relations which enhances my wiring, analyzing, concluding and interpretation skills and learned a lot from it.

This story also indicates that thesis writer was able to complete the work and enjoy the whole process because of his deep engagement with previous works, supervisors and other thesis writers. He was not only able to complete the work, but also developed essential academic writing skills. Therefore, academic writing in higher education needs to be taken as a social practice, not simply a technical and learnable language skill rather it is always embedded in socially constructed epistemological principles (Street, 2015). Street earlier in 1984, viewing literacy as a plural concept, coined the term ideological and the other is autonomous which is seen as a unitary concept without reference to contexts.

Under the socio-cultural framework, master's level students as novice researchers and writers gradually learn to access university culture, understand disciplinary discourses, and engage themselves in different academic writing activities in their academic communities. They learn to write from others as an outcome of academic socialization such as discussing their writing drafts with their supervisors, sharing research and writing ideas with peers and upper-grade students, seeking language help from doctoral students and preparing papers for conference presentations. During their engagement in several writing activities, they negotiate with their own life experiences and worldviews or diverse ideologies. Here, the 
writing is not viewed as a text production activity; but a range of practices centering around the writing act, including reading sources, teachers' guidelines and comments, advice and guidance from peers as well as teachers, and their own reflections on and observations of their learning experiences (Fujioka, 2007). The final output -the thesis -is the product of negotiation and renegotiation of different disciplinary and institutional ideologies. In the end, the learning from the thesis writing journey changes the thesis writer's identity and he or she possibly becomes an entirely different person.

\section{Conclusion}

Many thesis writers in Nepal view thesis writing as a 'ritual' activity. Against this backdrop, the universities' departments should come up with an appropriate and effective package of thesis writing with theoretical and practical clarity and make the students understand the value of thesis writing - a learning experience, an opportunity to enhance their academic writing skills and a process-based academic practice -in the university. Thus, changing the view of a one-way assimilation into a relatively stable academic community with fixed rules and conventions (Morita, 2004) to the collaborative writing practice which takes account of socio-cultural aspects of the writing is really important at present.

The study primarily supports that thesis writing as a socio-cultural practice involves several collaborative activities of reading and writing. Thesis writers collaborate with teachers, supervisors, department heads, peers, upper-grade students, conference organizers, and even publishers. During this dynamic process of academic socialization, they learn institutional and disciplinary conventions of reading and writing, and increase their participation in different activities. It gradually builds confidence in research and writing a thesis. The study also shows that understanding thesis writing as a socio-cultural practice in the university than a ritual, to a greater extent, helps to eliminate unethical conducts during the thesis writing stage in higher education in Nepal.

\section{Note by the author}

Some relevant parts of the article were borrowed from the blog piece I published earlier in January, 2021 at www.eltchoutari.com, an ELT web magazine. I framed it to give it a shape of article to publish in a local academic journal for my $\mathrm{PhD}$ purpose. 


\section{References}

Beard, C. Clegg, S. \& Smith, K. (2007). Acknowledging the affective in higher education. British Educational Research Journal, 33 (2), 235-252.

Bhattarai, A. (2009). The first activity in research. Journal of NELTA, 14(1), 21-25.

Casanave, C. P. (2002). Writing games: Multicultural case studies of academic literacy practices in higher education. Mahwah, NJ: Lawrence Erlbaum.

Casanave, C. P. (2003). Looking ahead to more sociopolitically-oriented case study research in L2 writing scholarship. Journal of Second Language Writing, 12, 85-102.

Darvin, R., \& Norton, B. (2019). Collaborative writing, academic socialization, and the negotiation of identity. In P. Habibie \& K. Hyland (Eds), Novice writers and scholarly publication (pp. 177- 194). Cham, Switzerland: Palgrave Macmillan.

Duff, P. A. (2010). Language socialization into academic discourse communities. Annual Review of Applied Linguistics, 30, 169-192.

Fujioka, M. (2007). Academic writing development as a socialization process: Implications for EAP education in Japan. PASAA, 40, 11-27.

Karn, S.K. (2009). Give me an easy topic, please: My experience of supervising theses. Journal of NELTA, 14(1), 63-70.

Kim, J. (2015). Understanding narrative inquiry: The crafting and analysis of stories as research. London: Sage publications.

Lave, J., \& Wenger, E. (1991). Situated learning: Legitimate peripheral participation. Cambridge: Cambridge University Press.

Lea, M., \& Street, B. (1998). Student writing and faculty feedback in higher education: An academic literacies approach. Studies in Higher Education, 23(2), 157-172..

Leibowitz, B., Goodman, K., Hannon, P. \& Parkerson, A. (1997). The role of a writing centre in increasing access to academic discourse in a multilingual university. Teaching in Higher Education. 2(1): 5-19.

McKinley, J. (2017). Identity construction in learning English academic writing in a Japanese university. The Journal of Asia TEFL 14 (2), 228-243.

Morita, N. (2004). Negotiating participation and identity in second language academic communities. TESOL Quarterly, 38, 573-603. 
Neupane Bastola, M. (2020). Engagement and challenges in supervisory feedback: Supervisors' and students' perceptions. RELC Journal, 1-15.

Pineteh, E. A. (2014). The Academic Writing Challenges of Undergraduate Students: A South African Case Study. International Journal of Higher Education. 3(1), 12-22.

Rai, M. (2018). Thesis writing: a hard nut to crack (a student's experience). In ELT Choutari. Available at: http://eltchoutari.com/2018/04/thesiswriting- a-hardnut-to-crack-a-students-experience.

Rai, T. (2018). Thesis writing: a next step in learning. In ELT Choutari. Available at: http://eltchoutari.com/2018/04/thesis-writing-a-hard-nut-to-crack-astudentsexperience.

Sharma, U. (2017). The role of supervisor and student for completing a thesis. Tribhuvan University Journal, 31(1-2), 223-238.

Street, B. (1984). Literacy in theory and practice. CUP: Cambridge.

Street, B. V. (2015). Academic writing: Theory and practice. Journal of Educational Issues, 1(2), 110-116.

Tiwari, H. P. (2019). Writing thesis in English education: Challenges faced by students. Journal of NELTA Gandaki (JoNG), 1, 45-52.

Wenger, E. (1998). Communities of practice: Learning, meaning, and identity. Cambridge, UK: Cambridge University Press.

Wilmot, K. \& Lotz-Sisitka, H. (2015). Supporting academic writing practices in postgraduate studies: A sourcebook of academic writing support approaches and initiatives. Centre for Postgraduate Studies: Rhodes University. 